\title{
Forced Expiratory Volume
}

National Cancer Institute

\section{Source}

National Cancer Institute. Forced Expiratory Volume. NCI Thesaurus. Code C120933.

The volume of gas an individual can forcible exhale from the lungs in one breath. 